\title{
De-Nol stimulates gastric and duodenal alkaline secretion through prostaglandin dependent mechanism
}

\author{
S J KONTUREK, J BILSKI, N KWIECIEN, W OBTULøWICZ, B KOPP, \\ AND J OLEKSY \\ From the Institute of Physiology, Academy of Medicine, Krakow, Poland
}

SUMmary This study was designed to determine the effects of colloidal bismuth subcitrate De-Nol on gastric $\mathrm{HCO}_{3}^{-}$secretion in 24 healthy subjects and on gastric and duodenal $\mathrm{HCO}_{3}^{-}$secretion in dogs with gastric and duodenal fistulae. Alkaline secretion was measured after pretreatment with ranitidine to abolish the $\mathrm{H}+$ secretion using a constant perfusion aspiration system and back titration of the perfusates to the original $\mathrm{pH} 6 \cdot 0$. Luminal release of $\mathrm{PGE}_{2}$ was also measured in the gastric and duodenal perfusates. Addition of De-Nol in gradually increasing concentrations resulted in step wise increments in gastric $\mathrm{HCO}_{3}^{-}$secretion in man and in dogs reaching, respectively, about $80 \%$ and $55 \%$ of the maximal $\mathrm{HCO}_{3}^{-}$response to 16,16 dimethyl- $\mathrm{PGE}_{2}$ $\left(\mathrm{dmPGE}_{2}\right)$. The duodenal $\mathrm{HCO}_{3}^{-}$response to De-Nol in dogs reached $72 \%$ of the $\mathrm{dmPGE}_{2}$ maximum. These effects were accompanied by a significant increase in luminal release of $\mathrm{PGE}_{2}$. Pretreatment with atropine reduced basal and in part De-Nol induced alkaline secretion, whereas pirenzepine did not affect this secretion in man and dogs. Aspirin (in man) and indomethacin (in dogs) reduced the release of $\mathrm{PGE}_{2}$ by about $80 \%$ and suppressed almost completely the gastric and duodenal $\mathrm{HCO}_{3}^{-}$response to De-Nol in these species. This study provides evidence that De-Nol stimulates gastroduodenal alkaline secretion through a prostaglandin dependent mechanism.

Bismuth compounds have been used for over two centuries for the treatment of various gastrointestinal disorders because of their local protective and demulcent properties. ${ }^{12}$ Colloidal bismuth subcitrate, which is the active ingredient of De-Nol, has been used successfully in peptic ulcer therapy because of its selective binding to the ulcer base, the protection against acid-pepsin attack, the stimulation of mucus secretion and its activity against Campylobacter pyloridis. ${ }^{1-3} \mathrm{De}-\mathrm{Nol}$ is neither an antisecretory agent

Address for correspondence: Prof Dr S J Konturek, Institute of Physiology, ul Grzegorzecka 16, 31-531 Krakow, Poland.

This study was supported in part by the grant MZ-III-15 of Polish Ministry of Health.

Received for publication 12 May 1987. nor an antacid, yet it has an impressive efficacy in the prevention of acute gastric lesions in experimental animals ${ }^{+}$and in healing of chronic peptic ulcers in man. ${ }^{5}$

Because alkaline secretion has been shown to play an important role in mucosal protection, particularly against luminal acid-pepsin aggression, ${ }^{6.4}$ in various species, including man, we decided to determine the influence of De-Nol on this secretion from the gastroduodenal mucosa. Alkaline secretion depends, in part, upon mucosal prostaglandins (PG) ${ }^{1111}$ and is under vagal cholinergic control. ${ }^{12} 13$ Thus attempts have been made to evaluate the effects of De- Nol on mucosal production of PG, and further the effects of blockade of cyclooxygenase and muscarinic receptors on De-Nol-induced alkaline secretion in man and in dogs have been examined. 


\section{Methods}

SUBJECTS

The study was approved by the Institutional Ethical Committee and informed consent was obtained from each subject tested.

The study was carried out on 24 male volunteers, 20-25 years (mean 21), and weighing 58-74 kg (mean weight $71 \mathrm{~kg}$ ). All subjects were in good health and without gastrointestinal disorder. Gastroduodenoscopy carried out before the start of the study revealed no abnormalities or peptic ulceration.

Several series of experiments were carried out on the same subjects with five to seven days washout between series. The evening before the examination and on the morning of examination, four tablets of ranitidine (1200 mg) (Glaxo, England) were given to completely suppress gastric acid secretion (luminal $\mathrm{pH} 7 \cdot 0$ or above) and thus prevent any conversion of $\mathrm{HCO}_{3}^{-}$into $\mathrm{CO}_{2}$. During the examination, a double lumen gastroduodenal Dreiling tube with endotracheal cuff was inserted and positioned fluoroscopically, the cuff being inflated (with $20 \mathrm{ml}$ water) in the duodenal bulb just beyond the pylorus. This prevented any escape of gastric perfusate into the duodenum and any reflux of the duodenal content into the stomach as described before. ${ }^{14} \mathrm{~A}$ polyethylene catheter attached to the Dreiling tube, with openings in the proximal part of the stomach was used to perfuse the stomach with saline adjusted to $\mathrm{pH} 6 \cdot()$, and containing phenol red as a nonabsorbable marker $(40 \mu \mathrm{g} / \mathrm{ml})$. Another polyethlene catheter attached to the Dreiling tube was filled with agar- $\mathrm{KCl}$ and served as a recording electrode for the measurement of the gastric potential difference (PD) in the oxyntic gland area. The potential difference, expressed in millivolts $(\mathrm{mV})$ referred to the polarity of the gastric lumen compared with the venous blood adjusted to zero. The distal portion of the Dreiling tube with wide lateral openings was located in the distal portion of the stomach for the continuous aspiration of the gastric content. The rate of perfusion was $600 \mathrm{ml} / \mathrm{h}$. This perfusion aspiration procedure was carried out throughout the examination. The volume of gastric aspirate was measured and $\mathrm{HCO}_{3}^{-}$ contents were determined by back titration of gastric perfusate to the original $\mathrm{pH}$ as described before. ${ }^{15}$ The samples of the perfusates were saved for phenol red determination by spectrophotometry at $520 \mathrm{~nm}$ and for $\mathrm{PGE}_{2}$ radioimmunoassay using $\mathrm{PGE}_{2}$ kits (New England Nuclear, Munich, FRG) as described before."111 it

In tests undertaken with De-Nol on 12 subjects (group A), gastric perfusion was first carried out with saline for 60 minutes and then De-Nol was added to the perfusate in gradually increasing concentrations
$(5-20 \mathrm{mg} / \mathrm{ml})$, each concentration being present for 60) minutes then doubled. At the end of the experiment, 16,16 -dimethyl-PGE $2\left(\mathrm{dmPGE}_{2}\right)$ was introduced into the stomach in the concentration of $5 \mu \mathrm{g} / \mathrm{ml}$ which had been shown in other tests to induce maximal $\mathrm{HCO}_{3}^{-}$output from the human stomach. ${ }^{17}$ In control tests the $\mathrm{HCO}_{3}^{-}$output were determined during gastric perfusion with saline without De-Nol for the duration of the experiment.

In a second series of tests done on six subjects (group B), gastric alkaline secretion was measured for a 60 minute period with De-Nol added to the perfusion fluid at a concentration of $20 \mathrm{mg} / \mathrm{ml}$. Ten micrograms per kilograms of atropine or pirenzepine was injected iv the perfusion aspiration procedure being carried out for the next 60 minute period. In control experiments, the response to $20 \mathrm{mg} / \mathrm{ml} \mathrm{De}$ Nol alone was carried out for the duration of the test $(120 \mathrm{~min})$.

Tests with aspirin (ASA) were carried out on six subjects (group $\mathrm{C}$ ); gastric $\mathrm{HCO}_{3}^{-}$response to De-Nol was measured during a 60 minute period with or without (control tests) pretreatment with $20 \mathrm{mg} / \mathrm{kg}$ ASA given po given about 60 minutes before the start of the examination.

STUDIES ON ANIMAIS

Six mongrel dogs $(16-20 \mathrm{~kg}$ ) were prepared with gastric fistulae (GF) and duodenal fistulae (DF). The procedure included the ligation of the accessory pancreatic duct and the diversion of bile and pancreatic juice from the duodenum to the upper jejunum by transplantation of the ducts with a piece of surrounding duodenum as described before. ${ }^{18}$ One cuff of Dacron mesh was placed around the proximal duodenum just beyond the pylorus and a second was placed around the mid-duodenum just proximal to the cannula of the duodenal fistulae. The cuffs were used to splint the duodenal wall and thus to seal the space between the wall and the inflated balloons of Foley catheter. Two connected Foley catheters were used during the experiment, one with a balloon inflated in the distal portion of the stomach to seal the gastroduodenal junction and another in the mid-duodenum to seal the distal end of the proximal duodenum. The gastric catheter was externalised through the gastric fistulae while the small polyethylene tube attached to it was used to perfuse the stomach. The duodenal catheter was externalised through the duodenal fistulae and used to drain the proximal duodenum between the balloons. A polyvinyl tube attached to the duodenal catheter was used to perfuse the duodenum. The perfused duodenum was about $5 \mathrm{~cm}$ long. The perfusion fluid contained a non-absorbable marker, phenol red, at a concentration of $40 \mu \mathrm{g} / \mathrm{ml}$. 
The whole stomach and the upper duodenum (between balloons) were perfused at a rate of $80 \mathrm{ml} / \mathrm{h}$ using saline adjusted to $\mathrm{pH} 6 \cdot 0$. The perfusates were collected separately by gravity drainage and pooled in 15 minute samples. The volume was measured and the amounts of $\mathrm{HCO}_{3}^{-}$in the perfusates were determined by back titration to the original $\mathrm{pH} 6 \cdot 0$ as in the human studies. The samples of the perfusates were also saved and frozen to $-20^{\circ} \mathrm{C}$ to determine the content of $\mathrm{PGE}_{2}$ using radioimmunoassay."' "1

The potential difference of the gastric and duodenal mucosa was also measured using recording electrodes in the form of $80 \mathrm{~cm}$ long polyethylene tubes filled with saturated $\mathrm{KCl}$ in $4 \%$ agar and placed along the Foley catheter in the proximal part of the stomach and in the upper duodenum. The reference electrode was connected to the peripheral vein as described before. ${ }^{15}$

Secretory studies started after about four to five weeks after surgery. Food, but not water, was withheld for about 18 hours before each experiment. Ranitidine $(20 \mathrm{mg} / \mathrm{kg})$ was injected iv to suppress gastric acid secretion and then both gastric and duodenal perfusions were started and assayed as in human studies.

Gastric and duodenal perfusions were first carried out for 60 minutes to determine basal $\mathrm{HCO}_{3}^{-}$secretion in each experiment. In tests with De-Nol, gradually increased concentrations $(10-80 \mathrm{mg} / \mathrm{ml})$ were added to the gastric and duodenal perfusion fluids, each concentration being administered for 60 minutes, and then doubled. During the final 60 minute period of the experiment dmPGE 2 was added to the perfusion fluid at a concentration of $5 \mu \mathrm{g} / \mathrm{ml}$ which has been shown to induce maximal $\mathrm{HCO}_{3}^{-}$secretion from the gastroduodenal mucosa in dogs..$^{15}$ In control tests, gastric and duodenal perfusions were done using saline without De-Nol for the duration of the experiment (240 minutes).

In other tests, atropine $(25 \mu \mathrm{g} / \mathrm{kg})$, pirenzepine (25 $\mu \mathrm{g} / \mathrm{kg})$ or indomethacin $(2.5 \mathrm{mg} / \mathrm{kg})$ was injected iv and then De-Nol was added to the gastric and duodenal perfusion fluids in gradually increasing concentrations as described above. In separate tests, basal $\mathrm{HCO}_{3}^{-}$secretion was measured for 60 minutes from the stomach and duodenum during their perfusion with saline (without De-Nol) and then atropine, pirenzepine or indomethacin was injected iv in the same doses as above, the perfusion being continued for the next 60 minute period.

STATISTICAL ANALYSIS

The results from experiments in human volunteers and in dogs are expressed as means + standard error of the means (SEM). Student's $t$ (paired) test was used to determine the statistical significance of differences. $p$ Values of less than $(0 \cdot 05$ were considered significant. ${ }^{-}$The increments in $\mathrm{HCO}_{3}^{-}$outputs in response to De-Nol alone or combined with atropine, pirenzepine or indomethacin (or ASA) were calculated by substracting the basal $\mathrm{HCO}_{3}^{-}$values from those recorded after De-Nol. The active ingredient of De-Nol, colloidal bismuth subcitrate, was uniformly used in these experiments. It was kindly supplied by Dr D W R Hall (Gist-Brocades NV, Delft, The Netherlands) as De-Nol spray dried powder and dissolved in saline. The original $\mathrm{pH}$ of that De-Nol solution was about 5.9 and it was adjusted to final $\mathrm{pH} 6.0$ by adding small amounts of $100 \mathrm{mM} \mathrm{NaOH}$.

\section{Results}

\section{STUDIES IN MAN}

The basal gastric $\mathrm{HCO}_{3}^{-}$secretion in 12 healthy subjects of group A was about $1100 \pm 260 \mu \mathrm{mol} / \mathrm{h}$ (mean $\pm \mathrm{SEM}$ ). The values of $\mathrm{HCO}_{3}^{-}$output fluctuated during the observation period within about $30 \%$ of the average value. After the addition of DeNol to the perfusion fluid there was a significant increase in $\mathrm{HCO}_{3}^{-}$outputs starting with $10 \mathrm{mg} / \mathrm{ml}$. With higher concentrations of De-Nol in the perfusion fluid $(20 \mathrm{mg} / \mathrm{ml})$ the $\mathrm{HCO}_{3}^{-}$outputs almost doubled and reached about $80 \%$ of the maximal response to dmPGE in these subjects (Fig. 1). In these tests with De-Nol stimulated alkaline secretion, the recovery of the phenol red marker infused into the stomach averaged about $96 \%$.

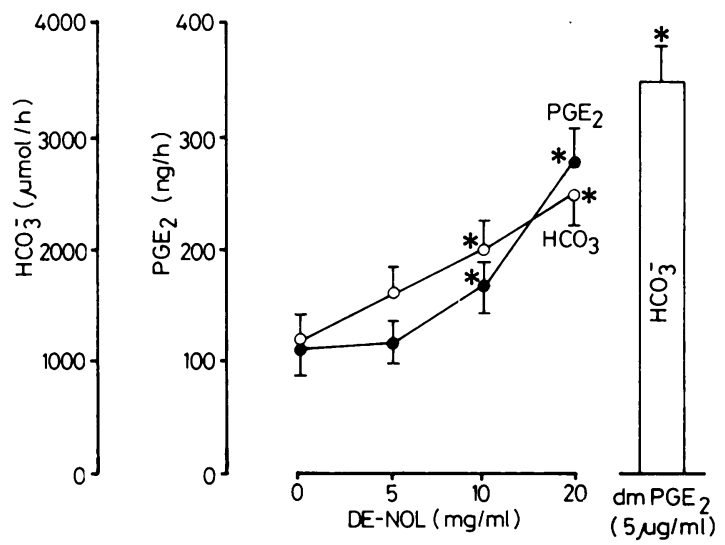

Fig. 1 Effects of gradually increasing concentrations of DeNol on gastric alkaline secretion and luminal release of $P G E_{2}$ in 12 healthy subjects (group A). For comparison, maximal $\mathrm{HCO}_{3}^{-}$response to 16, 16-dimethyl-PGE $E_{2}$ is presented. Mean $\pm S E M$ of 12 tests on 12 subjects. Asterisks indicate statistically significant $(p<0.05)$ increases above the basal value obtained with saline perfusion of the stomach. 

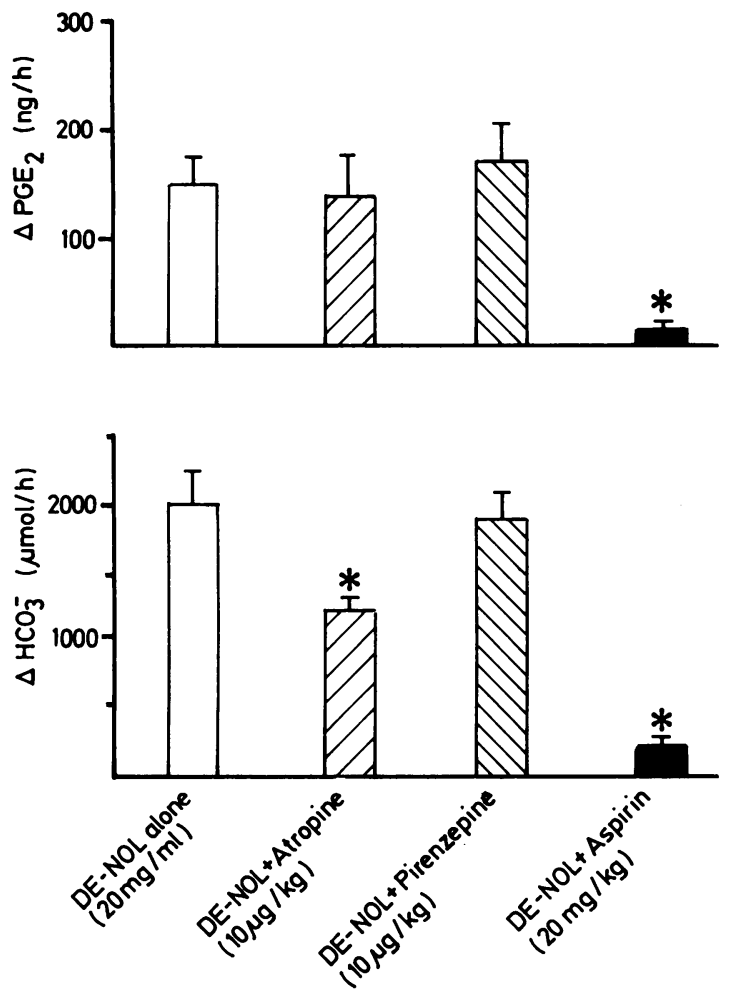

Fig. 2 Increments in gastric $\mathrm{HCO}_{3}^{-}$secretion and luminal $P G E_{2}$ outputs in tests of gastric perfusion with De-Nol alone and in combination with atropine or pirenzepine (group B subjects) and in combination with aspirin (group C subjects). Mean $\pm S E M$ of six tests on six subjects of group $B$ and $C$. Asterisks indicate statistically significant decreases $(p<0 \cdot 05)$ below the value obtained with De-Nol alone.

Basal $\mathrm{PGE}_{2}$ released into the gastric lumen saline perfusion averaged $118 \pm 20 \mathrm{ng} / \mathrm{h}$. Addition of DeNol at a dose of 10 and $20 \mathrm{mg} / \mathrm{ml}$ to the perfusion resulted in a significant increase in luminal release of $\mathrm{PGE}_{2}$ (Fig. 1).

Basal values of PD averaged $-32 \cdot 8 \pm 2 \cdot 6 \mathrm{mV}$. DeNol did not cause any significant change in the potential difference values at any concentration used and these results have been omitted for the sake of clarity.

Atropine $(10 \mu \mathrm{g} / \mathrm{kg})$ injected intravenously in six subjects of group $\mathrm{B}$ resulted in a significant reduction in basal $\mathrm{HCO}_{3}^{-}$output by about $64 \%$ and diminished the De-Nol $(20 \mathrm{mg} / \mathrm{ml})$ stimulated $\mathrm{HCO}_{3}^{-}$outputs by about $36 \%$. In contrast, pirenzepine at the same dose did not affect basal or De-Nol induced $\mathrm{HCO}_{3}^{-}$ secretion (Fig. 2). Neither atropine nor pirenzepine influenced basal or De-Nol stimulated luminal release of $\mathrm{PGE}_{2}$ in these tests (Fig. 2).
Pretreatment with ASA reduced basal $\mathrm{HCO}_{3}^{-}$ outputs by about $70 \%$ and that induced by De-Nol by about $80 \%$. Aspirin reduced basal release of $\mathrm{PGE}_{2}$ by about $85 \%$ and almost completely abolished the $\mathrm{PGE}_{2}$ release by De-Nol (Fig. 2).

STUDIES IN DOGS

In control tests with saline perfusion, basal gastric and duodenal $\mathrm{HCO}_{3}^{-}$outputs averaged $120 \pm 28$ and $185 \pm 42 \mu \mathrm{mol} / 30 \mathrm{~min}$, respectively. Basal $\mathrm{HCO}_{3}^{-}$ outputs during 240 minutes control period showed fluctuations within about $20-30 \%$ of the average value.

De-Nol added to the perfusion fluid resulted in a concentration dependent increase in $\mathrm{HCO}_{3}^{-}$outputs, reaching maximum at a concentration of $40 \mathrm{mg} / \mathrm{ml}$. This maximal gastric and duodenal $\mathrm{HCO}_{3}^{-}$reponse to De-Nol amounted to $55 \%$ and $72 \%$ of the respective maximal gastric and duodenal $\mathrm{HCO}_{3}^{-}$responses to dmPGE in these animals (Figs 3 and 4). The recovery rate of the duodenal perfusates in these tests ranged from $80-90 \%$.

In control tests with saline perfusion, the potential difference value in the body of the stomach averaged $-52.4 \pm 3.8 \mathrm{mV}$ and in the upper duodenum $-11.4 \pm$ $1.8 \mathrm{mV}$. Addition of De- $\mathrm{Nol}$ into the gastric or duodenal perfusate did not influence the potential difference value at any concentrations used.

$\mathrm{PGE}_{2}$ outputs in gastric and duodenal perfusates averaged $46 \pm 6$ and $71 \pm 12 \mathrm{ng} / \mathrm{h}$, respectively. Addition of De-Nol to the perfusion resulted in an

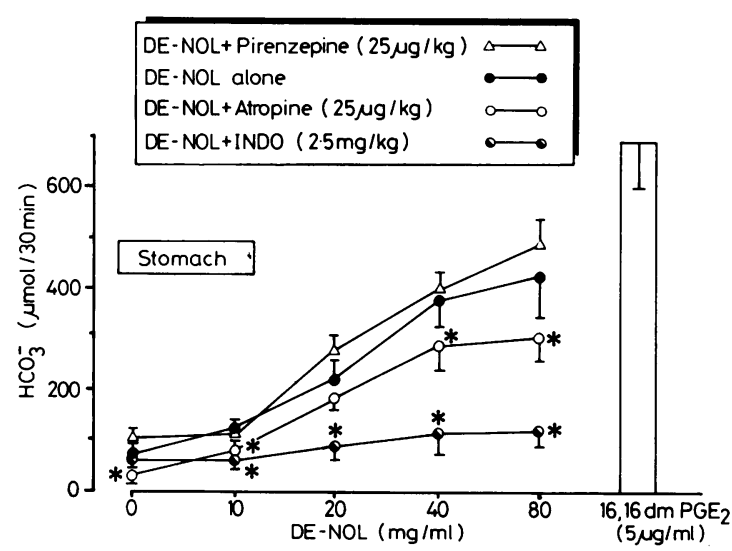

Fig. 3 Effects of gastric perfusion with gradually increasing concentrations of De-Nol on canine $\mathrm{HCO}_{3}^{-}$outputs in tests with De-Nol alone or combined with atropine, pirenzepine or indomethacin. For the comparison, the maximal $\mathrm{HCO}_{3}^{-}$ response to 16, 16-dimethyl $P G E_{2}$ is presented. Mean \pm $S E M$ of six tests on six dogs. Asterisks indicate statistically significant $(p<0.05)$ decreases below the value obtained with De-Nol alone. 


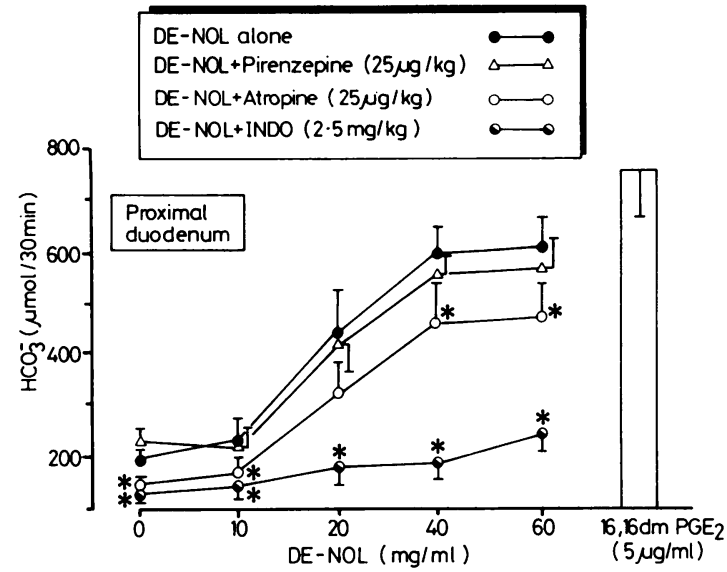

Fig. 4 Effects of duodenal perfusion with gradually increasing concentrations of De-Nol on canine duodenal $\mathrm{HCO}_{3}^{-}$output in tests with De-Nol alone or combined with atropine, pirenzepine or indomethacin. For the comparison, the maximal $\mathrm{HCO}_{3}^{-}$response to 16, 16-dimethyl $\mathrm{PGE}_{2}$ is presented. Mean $\pm S E M$ of six tests on six dogs. Asterisks indicate statistically significant $(p<0.05)$ decreases below the value obtained with De-Nol alone.

increase in $\mathrm{PGE}_{2}$ contents that were significant at 40 and $80 \mathrm{mg} / \mathrm{ml}$ concentrations of De-Nol (Table).

Injection of atropine $(25 \mu \mathrm{g} / \mathrm{kg})$ caused significant reduction in basal gastric and duodenal $\mathrm{HCO}_{3}^{-}$ outputs and decreased the $\mathrm{HCO}_{3}^{-}$response to De-Nol by $15-32 \%$ depending on the concentrations. Pirenzepine $(25 \mu \mathrm{g} / \mathrm{kg})$ did not significantly affect basal or De-Nol induced gastric or duodenal $\mathrm{HCO}_{3}^{-}$ secretion (Figs 3,4). Neither atropine nor pirenzepine influenced basal or De-Nol induced luminal release of $\mathrm{PGE}_{2}$ (Table).

Indomethacin $(2.5 \mathrm{mg} / \mathrm{kg})$ did not change significantly basal gastric $\mathrm{HCO}_{3}^{-}$outputs but reduced by about $60 \%$ basal duodenal $\mathrm{HCO}_{3}^{-}$outputs. Indomethacin almost completely abolished gastric and duodenal $\mathrm{HCO}_{3}^{-}$responses to De-Nol (Figs 3 and 4). Indomethacin reduced by about $75 \%$ basal $\mathrm{PGE}_{2}$ release and abolished the $\mathrm{PGE}_{2}$ release induced by De-Nol (Table).

\section{Discussion}

This study provides evidence that De-Nol (colloidal bismuth subcitrate) stimulates gastric and duodenal alkaline secretion and that this depends, at least in part, upon the mucosal generation of prostaglandins.

Previous studies showed that alkaline secretion by gastric and duodenal mucosa is an energy dependent process that is under local humoral control involving mucosal prostaglandin " " and under neural control
Table PGE content ( $\mathrm{ng} / \mathrm{h}$ ) of gastric and duodenal perfusates obtained drug saline perfusion (basal) and after addition of De-Nol alone or in combination with atropine, pirenzepine or indomethacin in dogs. Mean $\pm S E M$ of six tests on six dogs.

\begin{tabular}{|c|c|c|c|}
\hline \multirow[b]{2}{*}{ Group } & \multirow[b]{2}{*}{ Dose } & \multicolumn{2}{|c|}{ PGE $E^{2}$ Output $(n g / h)$} \\
\hline & & Stomach & Duodenum \\
\hline Basal & Saline & $46 \pm 6$ & $71 \pm 12$ \\
\hline De-Nol & $5 \mathrm{mg} / \mathrm{ml}$ & $50 \pm 7$ & $76 \pm 10$ \\
\hline$"$ & $10 \mathrm{mg} / \mathrm{ml}$ & $62 \pm 8$ & $85 \pm 14$ \\
\hline$"$ & $20 \mathrm{mg} / \mathrm{ml}$ & $75 \pm 10^{*}$ & $96 \pm 11^{*}$ \\
\hline$"$ & $40 \mathrm{mg} / \mathrm{ml}$ & $82 \pm 12^{*}$ & $124 \pm 28^{*}$ \\
\hline$"$ & $80 \mathrm{mg} / \mathrm{ml}$ & $98 \pm 16^{*}$ & $130 \pm 18^{*}$ \\
\hline De-Nol & $20 \mathrm{mg} / \mathrm{ml}$ & $72 \pm 12^{*}$ & $104 \pm 14^{*}$ \\
\hline De-Nol $\ddagger \dagger$ & Atropine $25 \mu \mathrm{g} / \mathrm{kg}$ & $82+17^{*}$ & $97 \pm 12^{*}$ \\
\hline De-Nol* $\ddagger \dagger$ & Pirenzepine $25 \mu \mathrm{g} / \mathrm{kg}$ & $79 \pm 18^{*}$ & $110 \pm 16^{*}$ \\
\hline De-Nol $\ddagger \dagger$ & Indomethacin $2.5 \mathrm{mg} / \mathrm{kg}$ & $18 \pm 4 \dagger$ & $23 \pm 6 \dagger$ \\
\hline
\end{tabular}

${ }^{*}$ Statistically significantly higher than the basal values (saline); $\dagger$ Statistically significantly lower than the value obtained with De-Nol $(20 \mathrm{mg} / \mathrm{ml}) ; \ddagger$ De-Nol was perfused at $20 \mathrm{mg} / \mathrm{ml}$.

involving a vagal cholinergic component. ${ }^{12} 13$ The stimulation of the gastric or duodenal $\mathrm{HCO}_{3}^{-}$secretion by the presence of acid in the gut lumen is well documented in various species. ${ }^{7}$ The involvement of the mucosal generation of prostaglandin has been documented by direct determination of its increased release from the mucosa exposed to acid" and by the demonstration that the blockade of cyclooxygenase by indomethacin abolishes both the release of prostaglandin and $\mathrm{HCO}_{3}^{-}$secretion induced by mucosal acidification. ${ }^{411}$

Furthermore, most of the exogenous prostaglandin of the $\mathrm{E}$ and $\mathrm{F}$ series, particularly their methylated analogues, induce copious alkaline secretion after their topical application to the gastroduodenal mucosa. ${ }^{15}$ This study has utilised the methylated PGE analogue to elicit the maximal secretory capacity for $\mathrm{HCO}_{3}^{-}$both in human gastric mucosa and canine gastroduodenal mucosa.

The major finding of this report is the demonstration that the topical application of De-Nol in gradually increasing concentrations results in a concentration dependent increase in alkaline secretion both from the gastric and duodenal mucosa. In human stomach, the highest $\mathrm{HCO}_{3}^{-}$output in response to De-Nol reached about $80 \%$ of the dmPGE induced maximal $\mathrm{HCO}_{3}^{-}$secretion and in canine stomach it attained about $55 \%$ of the dmPGE maximum. In the canine duodenum the respective $\mathrm{HCO}_{3}^{-}$response to De-Nol reached $72 \%$ of the prostaglandin-maximum. Because the concentrations of De-Nol used in our study were within the range which may occur in the stomach or duodenum after ingestion of the therapeutic dose of this agent (single 
tablet of De-Nol is $300 \mathrm{mg}$ colloidal bismuth), it may be concluded that the stimulation of alkaline secretion belongs to the spectrum of pharmacological actions of De-Nol. This $\mathrm{HCO}_{3}^{-}$stimulatory effect may contribute to the therapeutic effects of the drug.

The mechanism of the alkaline stimulatory action of De-Nol is not immediately obvious. It is known for example that any mucosal damage results in copious alkaline secretion because of increased mucosal permeability and passive $\mathrm{HCO}_{3}^{-}$diffusion from the extracellular fluid into the gastric lumen. ${ }^{719}$ There is no evidence that De-Nol causes such damage to the gastroduodenal mucosa as the transmucosal potential difference which is an indicator of the mucosal integrity, was not affected by the drug. The fact that the increase in gastroduodenal alkaline secretion was paralleled by the rise in luminal release of $\mathrm{PGE}_{2}$ suggests that local prostaglandin may be involved in the De-Nol stimulated alkaline secretion. The crucial role of prostaglandin in the mechanism of De-Nol stimulated alkaline secretion is supported by our finding that aspirin or indomethacin, which are potent inhibitors of cyclooxygenase, ${ }^{2 \prime}$ abolished both the alkaline secretion and the release of prostaglandin in response to De-Nol.

Colloidal bismuth subcitrate has been previously reported to stimulate mucus secretion and to form a local protective barrier, especially over the ulcerated area. ${ }^{124}$ Stimulation by De-Nol of alkaline secretion into the mucus gel adherent to the epithelial surface may enhance mucosal protection, particularly against the damaging effect of luminal acid and pepsin.

Gastroduodenal alkaline secretion may also be stimulated by vagal-cholinergic excitation. Vagal stimulation by sham feeding was reported to increase this stimulation, ${ }^{712}$ whereas anticholinergics were found to cause the inhibition of this secretion. ${ }^{72}$ Safsten and Flemstrom ${ }^{21}$ reported recently that pirenzepine, which is classified as an M1-selective muscarinic antagonist, increased rather than inhibited the duodenal alkaline secretion possibly by acting through the M1 receptors in the brain. Thus we compared the influence of atropine and pirenzepine on basal and De-Nol stimulated alkaline secretion in man and dogs. We confirmed that atropine strongly suppressed basal alkaline secretion but had only little influence on the increase of alkaline secretion in response to De-Nol. Pirenzepine did not affect basal or De-Nol induced alkaline secretion from the stomach or duodenum. Neither of the antimuscarinic agents affected mucosal formation of $\mathrm{PGE}_{2}$. We found that atropine strongly reduced basal gastroduodenal alkaline secretion in human subjects and in dogs, whereas pirenzepine did not interfere with that secretion, which indicates that muscarinic receptors are involved in the mechanism of alkaline secretion.
This study was supported in part by Research Grant 501/R/18 from Polish Ministry of Health.

\section{References}

1 Wieriks J, Hespe W, Jaitly KD, Koekkoek PH, Lavy U. Pharmacological properties of colloidal bismuth subcitrate CBS (De-Nol). Scand J Gastroenterol 1982; 17: suppl 80: 11-6.

2 Coghill S. Experimental studies using colloidal bismuth subcitrate: possible mode of action. In: Axon ATR, ed. Pathogenesis and treatment of peptic ulcer disease. Amsterdam: Excerpta Medica, 1985: 7-12.

3 Marshall BJ, McGechie DB, Rogers PA, Glancy RJ. Pyloric campylobacter infection and gastroduodenal diseases. Med J Aus 1985; 142: 439-44.

4 Konturek SJ, Radecki T, Piastucki I, Drozdowicz D. Advances in the understanding of the mechanism of cytoprotective action of colloidal bismuth subcitrate. Scand J Gastroenterol 1986; 21: suppl 122: 6-10.

5 Tytgat GNJ, Hameeteman W, Van Olffen GW. Sucralfate, bismuth compounds substituted benzimidazoles, trimipramine and pirenzepine in the short and long-term treatment of duodenal ulcer. Clin Gastroenterol 1984; 13: 543-60.

6 Flemstrom G, Turnberg LA. Gastroenterol defence mechanisms. Clin Gastroenterol 1984; 13: 327-54.

7 Flemstom G. Gastric and duodenal mucosal bicarbonate secretion. In: Johnson LR, ed. Physiology of the gastrointestinal tract. New York: Raven Press, 1986: 842-67.

8 Konturek SJ. Gastric cytoprotection. Scand J Gastroenterol 1985; 20: 543-53.

9 Flemstrom G, Garner A. Gastroduodenal $\mathrm{HCO}^{3}$ transport: characteristics and proposed role in acidity regulation and mucosal protection. Am J Physiol 1982; 242: G183-93.

10 Konturek SJ, Bilski J, Tasler J. Gastroduodenal alkaline response to acid and taurocholate in conscious dogs. Am J Physiol 1984; 247: G149-54.

11 Konturek SJ, Bilski J, Tasler J, Konturek JW, Bielanski W, Kaminska A. Role of endogenous prostaglandins in duodenal alkaline response to luminal hydrochloric acid or arachidonic acid in conscious dogs. Digestion 1986; 34: $268-74$.

12 Forsell H, Stenquist B, Olbe L. Vagal stimulation of human gastric bicarbonate secretion. Gastroenterology 1985; 89: 581-6.

13 Konturek SJ, Bilski J. Tasler J. Cephalic phase of gastric and duodenal alkaline secretion in conscious dogs. Gastroenterology 1986; 90: 1499.

14 Konturek SJ, Biernat J, Kwiecien N, Oleksy. Effect of glucagon on meal-induced gastric secretion in man. Gastroenterology 1975; 68: 448-54.

15 Konturek SJ, Tasler J, Bilski J, Kania J. Prostaglandins and alkaline secretion from oxyntic antral and duodenal mucosa. Am J Physiol 1983; 245: G539-46.

16 Konturek SJ, Kwiecien N, Obtulowicz, et al. Effect of carprofen and indomethacin on gastric functions, mucosal integrity and generation of prostaglandins in man. Hepato-Gastroenterology 1982; 29: 267-70. 
17 Konturek SJ, Kwiecien N, Obtulowicz W, Thor P, Konturek JW, Oleksy J. Vagal-cholinergic control of gastric alkaline secretion in normal subjects and duodenal ulcer patients. Gut 1987; 28: 739-44.

18 Konturek JS, Thor P. Relation between duodenal alkaline secretion and motility in fasted and sham-fed dogs. Am J Physiol 1986; 251: G591-6.

19 Swierczek JS, Konturek SJ. Gastric alkaline response to mucosa-damaging agents; effect of 16, 16-dimethyl prostaglandin E2. Am J Physiol 1981; 241: G509-15.

20) Vane JR. Inhibition of prostaglandin synthesis is a mechanism of action for aspirin-like drugs. Nature 1971; 21: $232-5$.

21 Safsten B, Flemstrom G. Stimulatory effect of pirenzepine on mucosal bicarbonate secretion in rats duodenum in vitro. Acta Physiol Scand 1986; 127: 267-8. 